\title{
It's More than Just Debating: The Political Participation and Democratic Attitudes of Debate Programme Participants in Seven "New" Democracies"
}

\author{
Anne Valkering, Miroslav Nemčok, George Matu, \\ Peter Spáč
}

\begin{abstract}
This study is focused on the democratic competencies and political participation of young people taking part in debate programs in seven "new" democracies - the Czech Republic, Estonia, Latvia, Lithuania, Macedonia, Romania and Slovakia. The research employs conventional methods adopted from various established surveys for capturing the political attitudes and values of youths. Using a longitudinal research design, we compare results from debaters and their non-debating peers on three dimensions: political competence, democratic values and political participation. The results of the pre-tests indicate that debaters' attitudes are more in accordance with what a democratic theory would expect from active and engaged citizens. Participating in debate activities did not reveal significant attitudinal improvements during the short timeframe of our research (one school year), but the initial differences between debaters and non-debaters remained stable over time.
\end{abstract}

KEY WORDS debating; democratic values; electoral participation; issue-based participation; new democracies; political participation; youth

\section{Introduction}

Contemporary youth are often described as indifferent and passive citizens because of their dreadfully low electoral participation (Quintelier 2007: 177). However, just because their parents were likelier to go to the polling stations when they were the same age, does not necessarily make young people apolitical. In fact, contemporary young people have simply "reinvented political activism" (Norris 2002) and instead of electoral politics, they are more often engaged with non-institutionalised forms of political participation (Amnå and Ekman

Sociální studia / Social Studies 2/2018. Pp. 35-53. ISSN 1214-813X.

1 The authors would like to thank two anonymous reviewers for their helpful comments. Anne Valkering would like to acknowledge the generous support of the Erasmus + programme for the International Debate Education Association's (IDEA) project "From Measuring to Learning: Evaluating the Impact of Debate" and the support of IDEA's partners in this project. Miroslav Nemčok and Peter Spáč would like to acknowledge the generous support of the Czech Science Foundation through the grant project "Radicalization of Politics in Central Europe in Times of Crises" (GA17-09296S) which allowed them to participate in this inquiry. 
2014; Bennett and Segerberg 2012; Klingemann and Fuchs 1998; Norris 2003; Torney-Purta 2009) which includes occupations, campaigning for petitions, protests, activism through the internet, or simply displaying badges or stickers stating their political opinion on everyday objects (Bennett and Segerberg 2013; European Commission 2007; Sloam 2016).

Young people's trust in and knowledge of politics is low, but it is similar to that of older generations. Together with their lower level of political maturity, this does affect their willingness to participate in politics (Bergh 2013; Chan and Clayton 2006; Massing 2002; Quintelier 2007). Thus, finding the means by which young people's political maturity and knowledge increases may be an important step to increase more traditional political participation. However, recent studies on participation of youth in civic activities tend to be focused on young people in Western democracies. Since the patterns of democratic behaviour in the "old" and "new" democracies vary significantly (Kitschelt et al. 1999), it is surprising that conclusions reached in Western democracies are expected to hold true in other contexts.

Our paper focuses on "new" democracies and broadens the picture of contemporary youth political participation. The research was conducted in seven countries - the Czech Republic, Estonia, Latvia, Lithuania, Macedonia, Romania, and Slovakia. However, instead of assessing current levels of political participation in all of these countries, we explored one specific means by which the political participation of youths could be facilitated competitive debating. Given the overall characteristics of competitive debating, we expect that it improves the skills essential for the deepening of political engagement (Allen et al. 1999; Burdewick 2003; Colbert 1987; Cronin 1990; Ennis 1987; Goodwin 2003; Green and Klug 1990; Jerome and Algarra 2006; Kennedy 2009). Therefore, we focus on the impact on individual attitudes of participation in debate programmes, in order to find out whether they fulfil the assumed mission openly declared by the organisations responsible for competitive debate in the selected countries - to bring up more politically active and engaged citizens.

In the current study, we first present a literature review of the role of political/civic education on youth political participation to explain our focus. We then discuss why competitive debating is expected to stimulate youth political interest and lead to higher participation rates. In the last part, we describe the conducted research study and present the results based on originally collected empirical evidence on democratic competence, democratic attitudes, and on the political participation of youths who do and do not participate in debate programmes.

\section{Civic education and youth political participation}

Stadelmann-Steffen and Sulzer (2017) identify two elements that conjointly determine an individual's political participation: (1) capacity to participate and (2) motivation to participate. Capacity depends on an individual having "basic knowledge about the political system, relevant actors, and the political process, and the ability to make decisions on political issues (self-efficacy)," as well as "civic skills [...], which refer to the communicative and organizational capacities that facilitate effective political 
involvement" (Stadelmann-Steffen and Sulzer 2017: 4). The second element, motivation, is based purely on a willingness to participate, which can be defined as "one's desire to engage with politics, which also is related to whether political participation is expected by the environment or by norms or tradition" (Stadelmann-Steffen and Sulzer 2017: 5).

Civic/political education at high schools should help young citizens with an understanding of democratic procedures and allow them to participate in politics (Rhomberg 2009: 161). Its aim is to provide students with skills that can help them to obtain, analyse, and utilise information about the political system, to make competent political decision (Owen, Chalif and Soule 2011) and enable more complex understanding of multiple perspectives and arguments for a single problem and how they are interrelated (Gomez and Wilson 2001).

However, the evidence suggests that even though various civic education programs may increase students' civic engagement at the school or community level (Lin 2015; Reichert and Print 2017), the overall impact on young people's political participation is rather limited (e.g. McAllister 1998; Nugent 2006; Stadelmann-Steffen and Sulzer 2017), and how long the potential impact lasts remains a question (Lin 2015: 23-24).

Despite their limited overall impact, more fine-grained analyses have discovered that civic/political education activities have an actual impact if they are conducted as a role play or a political simulation (Lin 2015) taking place in informal settings (Kirlin 2002; McFarland and Starmanns 2009; McFarland and Thomas 2006; Mirazchiyski, Caro and SandovalHernández 2014; Youniss, McLellan and Yates 1997). At the same time, they mostly improve the skills required for effective political involvement, rather than increase knowledge or increase political interest (Stadelmann-Steffen and Sulzer 2017).

\section{Debate as a stimulus of youths' political interest}

An activity aimed at increasing youths' political engagement should ideally focus on political skills, knowledge, and interest. Debating is a simulation of a political discussion which takes place in the informal settings of debate clubs or debate tournaments, aimed at the development of skills such as public speaking, conducting research, thinking quickly and critically, and constructing persuasive arguments (Bellon 2000). If it is essential for a person to have basic communicative skills so that they can understand and perceive the rules and values of politics more easily and thereby participate more actively in it (Burdewick 2003: 37), then we believe that these communicative skills largely overlap with the set of skills developed through debating. That is exactly the reason why we have decided to conduct our study on young people participating in the debate programmes throughout European countries. Despite variations in the formats of competitive debating, all of them have one crucial thing in common: participants intellectually defend positions regardless of their own opinion. This occurs either through random allocation of positions in debate tournaments or because they have to debate both sides of a motion in separate rounds. They often prepare and research both sides of motions known in advance, which prompts them to learn more about the intellectual bases of their own and other people's views. 
The necessity of approaching a debate topic from various perspectives and intellectually defending the side which has been randomly assigned, apparently leads to the advancement of critical thinking and stands at the very core of what Owen, Chalif and Soule (2011) perceive as political discussion. Improvement in critical thinking represents the best documented benefit of competitive debating (Bellon 2000), which has been empirically proven by numerous studies regardless of the chosen definition of critical thinking (Allen et al. 1999; Colbert 1987; Cronin 1990; Ennis 1987; Goodwin 2003; Green and Klug 1990; Jerome and Algarra 2006; Kennedy 2009). ${ }^{2}$ It is the same competence - critical thinking - which is repeatedly mentioned by experts on civic education as a crucial aspect in determining the understanding of rules and values that build up a democratic society (Beer, Cremer and Massing 1999; Burdewick 2003; Rhomberg 2009; Yoldaş 2015). Therefore, it is reasonable to expect that participation in competitive debating develops skills and improves understanding of democratic values and processes which are essential for active political participation in democratic systems.

However, the essential competences for political participation and actual political participation are two different things. A much more important question is whether debaters demonstrate more active political engagement compared to their peers. In this respect, empirical research provides certain indices. Some authors have found that debaters are more likely to vote, do outside-university volunteer work, take part in political volunteerism (such as volunteer work for a political party), hold membership in political university societies or a student body, and participate in social advocacy volunteer work (Bartanen 1998; Brand 2000; Derryberry 1997; Rogers 2002). However, there has been no research conducted yet which is focused on debaters and their level of political engagement and participation in democratic procedures. This is the gap in the literature we would like to fill. Moreover, this study is of high social relevance because the empirical evidence presented in the above-mentioned studies suggests that competitive debating could be a useful tool in solving the problem of young people's lack of competences and political disengagement in the democratic system, especially in countries with a short democratic tradition.

Based on the reviewed literature, we formulate the following set of hypotheses:

H1: Competence hypothesis: Participation in a debate programme increases competencies for democratic political participation of youths.

H2: Attitudinal hypothesis: Participation in a debate programme increases young people's support for democracy and democratic values.

H3: Participation hypothesis: Participation in a debate programme increases youths' willingness to electoral as well as non-electoral (i.e. issue-based) political participation.

\section{Data and methods}

In our quantitative study of young people's political competencies, democratic attitudes, and political participation in "new" democracies, we surveyed a sample of high school

2 Given the scope of our study, it must be mentioned that most of the studies were conducted in Western countries. 
students at the beginning and end of the academic year 2015/2016 in the Czech Republic, Estonia, Latvia, Lithuania, Macedonia, Romania, and Slovakia. A team of evaluators in each country was responsible for data collection and cooperated closely with debate coaches and/ or the schools where the research took place. ${ }^{3}$ Our aim was to compare the declared attitudes and political values of debate programme participants to those of their non-debating peers. In addition, we sought to establish whether other differences between the groups of debaters and non-debaters could explain any potential differences, such as socio-economic background or age, with a number of background questions.

The control group consisted of classmates of the debaters involved in the research. This strategy kept some important variables constant, e.g. teachers, school environment etc., so we did not have to control for them in subsequent analysis. This is different for Macedonia, where debate clubs are not located at high schools and, rather, host students from several schools. Instead, two high schools representing the diverse student population were selected to gather the control group data.

In addition to the questions included in this article, the questionnaire also contained two exercises which tested the critical thinking capabilities of respondents. These have been excluded from this analysis, as we focus here on political engagement and democratic attitudes. On the basis of our theoretical framework, we assumed that active participation in the debate programme would be associated with higher levels of democratic competencies, deeper support for democracy and democratic values, and more willingness for electoral and non-electoral political participation.

For the research, we sought existing social science research and well-established studies on comparable topics for our own survey questions. We used items from the European Values Survey (EVS) 2008 as much as possible, as they provided tested translations and concepts. In other cases, we used surveys of the political beliefs and values of Dutch/Flemish youth (Binnema, Adriaansen and Verhue 2007; Hooghe et al. 2013). The questionnaires were translated into the official languages of the participating countries where necessary and their reliability was tested in every country in a small pilot. The only questions which were not taken from more established studies are the ones designed to identify debate involvement.

The test setting differed in each country, and sometimes from pre-test to post-test, due to different circumstances in the countries. The pre-test in Estonia was conducted at their first-year tournament so as to reach all clubs efficiently, while the post-test was collected through the clubs. Respondents in the Czech Republic, Lithuania, Romania, and Slovakia did the tests at school. In Macedonia, they did so in a similar setting: their debate clubs. In Latvia, the survey was conducted in school, tournament, and home settings. The evaluators mostly

3 The research described here is part of a larger impact evaluation that the International Debate Education Association (IDEA NL) and seven of its member organisations implemented. Their aim is to teach critical thinking and communication skills and attitudes of ethical and inclusive debate to promote tolerance and further the exchange of reasoned arguments. The organisations teach public speaking and competitive debate to high school students and other groups, organise debate tournaments, and facilitate debate clubs. 
used the pen-and-paper method. Latvia and Lithuania employed electronic data gathering, while Estonia used a mix of both.

The comparison of several varying characteristics can be found in Table 1. However, in all of the cases, the data gathering procedures followed the given instructions, which were discussed during one of the preparatory meetings. Differences only occurred due to the need to adapt the procedures to the specific contexts of participating countries. Given the character of the questionnaire, we believe that slight differences in settings across countries do not constitute a problem for the general validity of the data. There is no reason to expect that different settings would result in significantly different conclusions.

Table 1: Comparison of data collection methods employed across countries

\begin{tabular}{|c|c|c|c|c|}
\hline & Sample & Control group & Setting & Survey method \\
\hline $\begin{array}{l}\text { Czech } \\
\text { Republic }\end{array}$ & $\begin{array}{l}\text { All clubs reached, } \\
\text { those who } \\
\text { responded positively } \\
\text { participate }\end{array}$ & $\begin{array}{l}\text { Debaters' } \\
\text { classmates }\end{array}$ & School & Pen-and-paper \\
\hline Estonia & $\begin{array}{l}\text { All participants } \\
\text { at the tournaments }\end{array}$ & $\begin{array}{c}\text { Reached debaters' } \\
\text { classmates } \\
\text { and other students } \\
\text { from three chosen } \\
\text { schools }\end{array}$ & Tournament & $\begin{array}{l}\text { Pen-and-paper } \\
\text { and electronically }\end{array}$ \\
\hline Latvia & $\begin{array}{c}\text { All participants } \\
\text { reached via debate } \\
\text { coaches }\end{array}$ & $\begin{array}{c}\text { At two schools - one } \\
\text { urban, one rural }\end{array}$ & $\begin{array}{l}\text { At schools, at } \\
\text { home, partially } \\
\text { at a tournament }\end{array}$ & Electronically \\
\hline Lithuania & $\begin{array}{l}\text { All clubs reached, } \\
\text { those who } \\
\text { responded } \\
\text { positively } \\
\text { participate }\end{array}$ & $\begin{array}{l}\text { Debaters' } \\
\text { classmates }\end{array}$ & At schools & Electronically \\
\hline Macedonia & $\begin{array}{c}\text { All participants via } \\
\text { coaches }\end{array}$ & $\begin{array}{l}\text { Students at two } \\
\text { representative } \\
\text { schools }\end{array}$ & Debate clubs & Pen-and-paper \\
\hline Romania & $\begin{array}{l}\text { All clubs in two } \\
\text { regions reached, } \\
\text { those who } \\
\text { responded positively } \\
\text { participate }\end{array}$ & $\begin{array}{l}\text { Debaters' } \\
\text { classmates }\end{array}$ & Schools & Pen-and-paper \\
\hline Slovakia & $\begin{array}{l}\text { All clubs reached, } \\
\text { those who } \\
\text { responded positively } \\
\text { participate }\end{array}$ & $\begin{array}{l}\text { Debaters' } \\
\text { classmates }\end{array}$ & Schools & Pen-and-paper \\
\hline
\end{tabular}

Source: Authors based on conducted research

\section{Analysis}

To identify the differences between debaters and non-debaters, we conducted a series of independent two-sample t-tests (or its non-parametric equivalent) for multiple variables 
related to political competencies, democratic attitudes, and political participation. ${ }^{4}$ Taking into account the longitudinal design, the inferential analysis relied on the change/gain scores between the pre-test and post-test. We used variables composed of several items included in the survey: reversing the scores for items with negative wording, conducting a factor analysis and a reliability analysis for the underlying constructs, and computing the index variables or factorial scores. Although the initial survey questions mainly consisted of ordinal scales, the computed index variables and factor scores estimates are used in our analysis as linear scales. Samples size variations and cross-country differences for the wording of some items lead to lower internal consistency for some of the scales, with Cronbach's alpha falling in some instances below the generally accepted threshold of 0.7. For the national level analysis, the normality distribution assumption of the t-test was not always met in the countries with smaller sample sizes. While acknowledging all these limitations, we tried to structure the analysis in a manner that is both comprehensive and easy to follow for readers.

One particular limitation of our longitudinal survey was the high dropout rate (approximately $50 \%$ ) between the pre-test and the post-test. In case of the debaters, some of them quit the activity during the school year, while others were not able to attend the training meeting(s) when data collection for the post-test took place. We would expect the first group to differ in potentially meaningful ways from the overall group of debaters, but not the latter. Not attending school at the time when the post-test took place is also the main reason behind the high dropout rate for the control group. In some isolated cases, the teachers that helped the evaluators in the data collection process for the control group, applied the final evaluation questionnaires to a different classroom than the one initially included in the study. These results were excluded from the study. Also, for both debaters and non-debaters, we reported some instances where the anonymised identification code that we used matched only partially between the initial and final evaluation, so we had to exclude those cases from the analysis. Overall, the high dropout rate seems, for the most part, to be explicable by random factors, rather than factors that potentially decrease the reliability of the sample. While high dropout rates compromise the generalisability of the results, they do not, therefore, invalidate the results. The high dropout rate poses some problems when interpreting national level results in four of the countries in our study: Latvia, Estonia, Czech Republic, and Romania.

The results summarised in Table 2 indicate that at the beginning of the school year, debaters from our sample scored higher than their non-debating peers on almost all of the variables measuring political participation and democratic attitudes. Debaters are more likely to know more about politics, are better able to express political opinions, have a stronger support for democracy, are more tolerant of diversity, and are more likely to participate in politics. Using the classification proposed by Cohen (Field 2009), the sizes of the effects are relatively small. Nevertheless, the results are similar to the effects identified in other studies measuring outcomes associated with debate participation, such as critical thinking (Allen et al. 1999).

4 See the Appendix for a complete list of the questionnaire items included in the analysis. 
Table 2: Summary of overall results (pre-test comparison between debaters and control group)

\begin{tabular}{|c|c|c|c|c|}
\hline Variable & $\dagger$ & df & $p$ & Effect size $(r)^{*}$ \\
\hline \multicolumn{5}{|l|}{ H1: Competence hypothesis } \\
\hline Interest in political issues & 7.35 & 1302 & $<.001$ & .19 \\
\hline Political knowledge & 3.56 & 1253 & $<.001$ & .10 \\
\hline Understanding political opinions & \multicolumn{2}{|c|}{ Mann-Whitney U test } & $>.05$ & $\begin{array}{c}\text { Accept the null } \\
\text { hypotheses }\end{array}$ \\
\hline Expressing political opinions & \multicolumn{2}{|c|}{ Mann-Whitney U test } & $<.001$ & $\begin{array}{c}\text { Reject the null } \\
\text { hypotheses }\end{array}$ \\
\hline \multicolumn{5}{|l|}{ H2: Attitudinal hypothesis } \\
\hline Support for democracy & 5.08 & 1096 & $<.001$ & .16 \\
\hline Tolerance & 6.37 & 1198 & $<.001$ & .18 \\
\hline \multicolumn{5}{|l|}{ H3: Participation hypothesis } \\
\hline Electoral participation & 6.27 & 1303 & $<.001$ & .17 \\
\hline Issue-based participation & 7.14 & 1254 & $<.001$ & .19 \\
\hline
\end{tabular}

Note: Pearson correlation (r) is used as Effect size and was calculated based on the outputs of the independent t-tests. For further details, see Field (2009: 332-41).

Source: Authors based on conducted research

As will be further discussed below, the comparison between the first and second waves of the survey reveal roughly the same results, with only isolated statistically significant differences (Table 3). In Tables 4-9, we present detailed averages for the change scores for debaters and their peers included in the control group. As the analysis below shows, the limited change or no change results hold constant across the countries. Slightly extending beyond the scope of our research, we can argue that first-year debaters have attitudinal profiles that remain relatively constant despite the possible cultural differences. Moreover, the differences between debaters and non-debaters reported in the pre-test, tend to persist during one school year.

\section{H1: Democratic competence}

Our operationalisation of democratic competence assumes that more "competent" citizens should have a higher level of interest in political issues, should be more knowledgeable about political events, and should be able to understand politics and express political opinions with ease.

The overall data suggest that after one school year, the level of interest in political issues remained constant for both debaters and their peers. The only exception seems to be Romania, where debaters became significantly more interested in politics compared to the control group (Table 4). 
Table 3: Summary of overall results (change scores comparison between debaters and control group)

\begin{tabular}{|c|c|c|c|c|}
\hline Variable & $t$ & df & $p$ & Effect size ( $r)$ \\
\hline \multicolumn{5}{|l|}{ H1: Competence hypothesis } \\
\hline Interest in political issues & 0.00 & 734 & $>.05$ & \\
\hline Political knowledge & 0.28 & 622 & $>.05$ & \\
\hline Understanding political opinions & \multicolumn{2}{|c|}{ Mann-Whitney U test } & $>.05$ & $\begin{array}{c}\text { Accept the null } \\
\text { hypotheses }\end{array}$ \\
\hline Expressing political opinions & \multicolumn{2}{|c|}{ Mann-Whitney U test } & $>.05$ & $\begin{array}{c}\text { Accept the null } \\
\text { hypotheses }\end{array}$ \\
\hline \multicolumn{5}{|l|}{ H2: Attitudinal hypothesis } \\
\hline Support for democracy & -0.44 & 716 & $>.05$ & \\
\hline Tolerance & 0.66 & 667 & $>.05$ & \\
\hline \multicolumn{5}{|l|}{ H3: Participation hypothesis } \\
\hline Electoral participation & 0.78 & 730 & $>.05$ & \\
\hline Issue-based participation & 1.72 & 702 & $<.05$ & 0.06 \\
\hline
\end{tabular}

Note: Pearson correlation (r) is used as Effect size and was calculated based on the outputs of the independent t-tests for the change scores.

Source: Authors based on conducted research

Table 4: Average change scores for Interest in politics*

\begin{tabular}{|l|c|c|c|c|c|c|c|c|}
\hline & Overall & $\begin{array}{c}\text { Czech } \\
\text { Republic }\end{array}$ & Estonia & Latvia & Lithuania & $\begin{array}{c}\text { Macedo- } \\
\text { nia }\end{array}$ & Romania & Slovakia \\
\hline $\begin{array}{l}\text { Debate } \\
\text { (mean change) }\end{array}$ & $\mathbf{0 . 0 0}$ & -0.17 & 0.33 & -0.51 & 0.02 & -0.04 & $0.22^{*}$ & -0.0 \\
\hline $\begin{array}{l}\text { Control } \\
\text { (mean change) }\end{array}$ & $\mathbf{0 . 0 0}$ & 0.04 & -0.06 & 0.09 & -0.02 & 0.04 & -0.17 & 0.06 \\
\hline Sample size & $\mathbf{7 3 6}$ & 45 & 27 & 15 & 282 & 128 & 67 & 172 \\
\hline
\end{tabular}

Note: Statistically significant results at the $0.05 *$ level.

The Interest in politics variable was computed using factorial analysis for the four survey items presented in the Appendix. All four items loaded into a single factor and the factorial scores ranged between -2.80 and 2.50 . The change scores (differences between the post-test and pre-test) ranged between -3.11 and 3.87.

Source: Authors based on conducted research

On average, both debaters and non-debaters increased their level of political knowledge, with a slight difference favouring the debate group. But statistically significant results cannot be reported for the overall sample, nor for the individual countries. The only exception is Macedonia, where debaters in the post-test gave significantly more correct answers to the three knowledge questions regarding national politics (see Table 5). 
Table 5: Average change scores for Political knowledge

\begin{tabular}{|l|c|c|c|c|c|c|c|c|}
\hline & Overall & $\begin{array}{c}\text { Czech } \\
\text { Republic }\end{array}$ & Estonia & Latvia & Lithuania & $\begin{array}{c}\text { Mace- } \\
\text { donia }\end{array}$ & Romania & Slovakia \\
\hline $\begin{array}{l}\text { Debate } \\
\text { (mean change) }\end{array}$ & $\mathbf{0 . 3 4}$ & 0.44 & -0.35 & 0.12 & 0.48 & $0.33^{* *}$ & -0.31 & 0.53 \\
\hline $\begin{array}{l}\text { Control } \\
\text { (mean change) }\end{array}$ & $\mathbf{0 . 3 0}$ & 0.41 & -0.42 & 0.33 & 0.45 & -0.66 & -0.12 & 0.49 \\
\hline Sample size & $\mathbf{6 2 4}$ & 48 & 28 & 17 & 208 & 69 & 72 & 182 \\
\hline
\end{tabular}

Note: Statistically significant results at the $0.01^{* *}$ level.

The Political knowledge variable ranged between 0 and 3, indicating the number of correct answers given to the country-specific questions. The distribution of the change scores ranged between -3 and 3 .

Source: Authors based on conducted research

The overall average scores for the last dimension of democratic competence show that the debaters became only slightly more confident in their ability to understand political events, and somewhat more confident in their ability to formulate political opinions (see Table 6). However, only isolated statistically significant results (Mann-Whitney U test) can be reported (in Macedonia for understanding politics, and in Lithuania for formulating an opinion on political issues).

Table 6: Average change scores for Understanding and expressing political opinions

\begin{tabular}{|l|c|c|c|c|c|c|c|c|}
\hline & Overall & $\begin{array}{c}\text { Czech } \\
\text { Republic }\end{array}$ & Estonia & Latvia & Lithuania & $\begin{array}{c}\text { Macedo- } \\
\text { nia }\end{array}$ & Romania & Slovakia \\
\hline Understanding politics \\
\hline $\begin{array}{l}\text { Debate } \\
\text { (mean change) }\end{array}$ & $\mathbf{0 . 0 6}$ & -0.17 & -0.5 & 0.0 & 0.11 & $0.19^{*}$ & -0.20 & 0.01 \\
\hline $\begin{array}{l}\text { Control } \\
\text { (mean change) }\end{array}$ & $\mathbf{0 . 0 2}$ & 0.25 & -0.21 & -0.3 & 0.0 & -0.16 & 0.25 & 0.19 \\
\hline Sample size & $\mathbf{7 5 2}$ & 47 & 28 & 19 & 282 & 127 & 69 & 180 \\
\hline Formulate an opinion on political issues \\
\hline $\begin{array}{l}\text { Debate } \\
\text { (mean change) }\end{array}$ & $\mathbf{0 . 1 8}$ & 0.11 & 0.0 & 0.33 & $0.27^{*}$ & 0.01 & 0.22 & 0.15 \\
\hline $\begin{array}{l}\text { Control } \\
\text { (mean change) }\end{array}$ & $\mathbf{0 . 0 5}$ & 0.25 & 0.06 & 0.36 & -0.04 & -0.13 & 0.18 & 0.19 \\
\hline Sample size & $\mathbf{7 5 6}$ & 47 & 29 & 20 & 282 & 130 & 68 & 180 \\
\hline
\end{tabular}

Note: Since the variables are measured at the ordinal level, the central tendency of the distribution should be represented using the median. However, since the scale used only a few response categories, we observe the same median for the debate and control group. Therefore, means were computed in order to better represent the descriptive differences between the two groups. The inferential statistic results (i.e. the significant differences between the groups) are based on the Mann-Whitney U test.

Statistically significant results at the $0.05 *$ level.

Both variables were measured using a 5-point ordinal scale. The change scores for Understanding politics ranged between -4 and 4, while the change scores for Formulating an opinion on political issues ranged between -3 and 3 . Source: Authors based on conducted research 
One possible explanation has to do with the fact that participating even in just a few debate training sessions (when our data collection took place), makes students feel that some topics from the political agenda are quite difficult to grasp and require a huge amount of documentation in order to understand their full complexity. Thus making those with more knowledge unlikely to report more confidence in their understanding of politics.

The results reported in Table 2 show that students who join debate clubs are usually more "competent" citizens, having a greater interest in politics and a higher level of political knowledge, with similar results across the countries in our sample. Therefore, by trying to develop skills such as critical thinking, openness to dialogue, research skills etc., debate activities would hopefully represent a means through which the political interest of young students is consolidated. However, our data does not allow us to conclude that the political competencies of debaters are significantly improved after participating in a one year debate programme.

\section{H2: Democratic attitudes}

The overall sample comparison between the pre-test and post-test shows almost no change in support for the democracy and democratic government measurement (see Table 7). Although in some countries lower average scores were reported for the debate group, these trends were not statistically significant.

Table 7: Average change scores for Support for democracy

\begin{tabular}{|l|c|c|c|c|c|c|c|c|}
\hline & Overall & $\begin{array}{c}\text { Czech } \\
\text { Republic }\end{array}$ & Estonia & Latvia & Lithuania & $\begin{array}{c}\text { Macedo- } \\
\text { nia }\end{array}$ & Romania & Slovakia \\
\hline $\begin{array}{l}\text { Debate } \\
\text { (mean change) }\end{array}$ & -0.01 & 0.01 & -0.22 & -0.19 & -0.07 & 0.15 & -0.08 & 0.03 \\
\hline $\begin{array}{l}\text { Control } \\
\text { (mean change) }\end{array}$ & -0.01 & -0.14 & -0.06 & -0.03 & -0.05 & 0.16 & 0.04 & -0.01 \\
\hline Sample size & 718 & 48 & 29 & 20 & 275 & 117 & 63 & 166 \\
\hline
\end{tabular}

Note: The Support for democracy variable was computed as an index, based on the answers provided for seven survey questions. The survey items were measured using a 4-point ordinal scale. The reliability and factorial analysis suggested a unidimensional construct. The values for the change scores ranged between -1.57 and 2.00 . Source: Authors based on conducted research

The overall scores in Table 8 suggest that after one year, both debaters and non-debaters have slightly higher levels of openness towards other groups, with a minor, non-significant difference in the average change score favouring the debaters. For this particular dimension it is worth investigating whether the results reflect a genuine initial difference in the tolerance levels of debaters and non-debaters, or rather that there is a social desirability bias induced by the first debate meetings, where it is possible that rules of non-discrimination were 
established. For this purpose, further studies should use measurements that can differentiate between blatant and subtle forms of prejudice (Pettigrew and Meertens 1995).

Table 8: Average change scores for Tolerance

\begin{tabular}{|l|c|c|c|c|c|c|c|c|}
\hline & Overall & $\begin{array}{c}\text { Czech } \\
\text { Republic }\end{array}$ & Estonia & Latvia & Lithuania & $\begin{array}{c}\text { Mace- } \\
\text { donia }\end{array}$ & Romania & Slovakia \\
\hline $\begin{array}{l}\text { Debate } \\
\text { (mean change) }\end{array}$ & 0.11 & 0.09 & 0.00 & 0.18 & 0.09 & 0.22 & 0.19 & 0.03 \\
\hline $\begin{array}{l}\text { Control } \\
\text { (mean change) }\end{array}$ & 0.09 & 0.06 & 0.03 & 0.11 & 0.08 & 0.14 & 0.28 & 0.02 \\
\hline Sample size & 667 & 43 & 25 & 18 & 253 & 106 & 54 & 168 \\
\hline
\end{tabular}

Note: The Tolerance variable was computed as an index, based on the answers provided for 15 survey questions, regarding the acceptance of different minority groups as neighbours. The survey items were measured using a 4-point ordinal scale. The reliability and factorial analysis suggested a unidimensional construct of tolerance. The values for the change scores ranged between -1.93 and 2.08 .

Source: Authors based on conducted research

\section{H3: Political participation}

We asked respondents to indicate whether they have done, might do, or would never do a selection of political activities (see the Appendix for the list of items). The pre-test data capturing the trends in political participation showed that for both electoral participation and issue-based participation, debaters had higher average scores compared to the control group (Table 2). That means that debaters are more likely to engage in political activities or, at least, they see engagement as a reasonable opportunity.

Besides comparing the differences between debaters and non-debaters, our data allow us to explore the initial political participation profile of the students included in our sample. Tables 9 and 10 clearly suggest a higher level of engagement in the non-electoral forms of participation. These results are consistent and statistically significant for all countries but Latvia. Therefore, our data suggest that the shift towards issue-based forms of political participation documented for young people in Western democracies (e.g. Amnå and Ekman 2014; Bennett and Segerberg 2012; Klingemann and Fuchs 1998; Norris 2002, 2003; Sloam 2016; Torney-Purta 2009) holds true for East European youths. It is also worth noting that while both debaters and non-debaters are more engaged in non-electoral forms of participation, the debate group is more committed to this type of political engagement (effect size $r=0.45$, compared to $r=0.34$ for the non-debate group). 
Table 9: Group comparison of the scores for Electoral participation and Issue-based participation (pre-test)

\begin{tabular}{|l|c|c|c|}
\hline & Overall & Debate & Non-debate \\
\hline Issue-based participation & $\mathbf{1 . 9 9 * *}$ & $2.07^{* *}$ & $1.92^{* *}$ \\
\hline Electoral participation & $\mathbf{1 . 8 2}$ & 1.88 & 1.76 \\
\hline Sample size (df) & $\mathbf{1 2 7 6}$ & 628 & 621 \\
\hline Effect size (r) & $\mathbf{. 3 9}$ & .45 & .34 \\
\hline
\end{tabular}

Note: Statistically significant results at the $0.01 * *$ level.

Both Electoral participation and Issue-based participation were computed as index variables, based on the answers provided for five and six questions, respectively. The survey items were measured using a 3-point ordinal scale. The reliability and factorial analysis clearly suggested the delimitation between the two constructs. In the pre-test (and the post-test), the scores for the computed variables ranged between 1 and 3 .

Source: Authors based on conducted research

Table 10: Comparison of country scores for Electoral participation and Issue-based participation (pre-test)

\begin{tabular}{|l|c|c|c|c|c|c|c|c|}
\hline & Overall & $\begin{array}{c}\text { Czech } \\
\text { Republic }\end{array}$ & Estonia & Latvia & Lithuania & $\begin{array}{c}\text { Macedo- } \\
\text { nia }\end{array}$ & Romania & Slovakia \\
\hline $\begin{array}{l}\text { Issue-based } \\
\text { participation }\end{array}$ & $\mathbf{1 . 9 9 * *}$ & $2.10^{* *}$ & $1.91^{* *}$ & 1.76 & $1.94^{* *}$ & $1.90^{* *}$ & $2.02^{* *}$ & $2.23^{* *}$ \\
\hline $\begin{array}{l}\text { Electoral } \\
\text { participation }\end{array}$ & 1.82 & 1.90 & 1.83 & 1.77 & 1.84 & 1.70 & 1.80 & 1.89 \\
\hline
\end{tabular}

Note: Statistically significant results at the $0.01 * *$ level.

Source: Authors based on conducted research

The longitudinal analysis reveals no difference between debaters and non-debaters regarding electoral participation, and an overall significant increase in issue-based participation for the debate group (although the size of the effect is very small, $r=0.06$; see Table 11). By asking participants to debate on many different topics during one school year, or even at one tournament, debating can encourage a form of political participation that is closer to the issue-based type of participation that youths prefer.

The detailed longitudinal analysis seldom shows significant increases of the measured outcomes for debaters compared to their non-debating peers. However, after one school-year, the margin between the two groups remained roughly the same - debaters scored higher than non-debaters on almost all of the variables of interest (involvement in political activities, interest in political issues, political knowledge, support for democracy etc.), but with almost no statistically significant differences.

On one hand, we can confidently conclude that the above-mentioned characteristics are clearly associated with active respondents who actively participate in a debate programme. However, on the other hand, the question remains what the actual impact of debating itself is. We believe that the absence of any longitudinal effect was due to a methodological shortcoming. The period of several months (6-9) does not constitute a time-frame long enough to reveal significant differences in the political participation and attitudes of young 
people (especially if we take into account that an opportunity for active political participation comes only once in a while). Besides that, competitive debating is only a non-curricular activity and participation is strictly voluntary. Therefore, our sample may contain a selfselection bias (Sanders, Wiseman and Gass 1994), since students who are interested in joining a debate club might have higher initial levels of political engagement, critical thinking etc., compared to their peers.

Table 11: Average change scores for Electoral participation and Issue-based participation

\begin{tabular}{|l|c|c|c|c|c|c|c|c|}
\hline & Overall & $\begin{array}{c}\text { Czech } \\
\text { Republic }\end{array}$ & Estonia & Latvia & Lithuania & $\begin{array}{c}\text { Mace- } \\
\text { donia }\end{array}$ & Romania & Slovakia \\
\hline \multicolumn{7}{|l|}{ Electoral participation } \\
\hline $\begin{array}{l}\text { Debate } \\
\text { (mean change) }\end{array}$ & 0.05 & 0.18 & 0.04 & -0.02 & -0.00 & 0.07 & 0.7 & 0.15 \\
\hline $\begin{array}{l}\text { Control (mean } \\
\text { change) }\end{array}$ & 0.05 & 0.06 & 0.16 & 0.05 & -0.02 & 0.03 & 0.8 & 0.13 \\
\hline Sample size & 732 & 47 & 29 & 20 & 272 & 120 & 68 & 176 \\
\hline \multicolumn{7}{|l|}{ Issue-based participation } \\
\hline $\begin{array}{l}\text { Debate } \\
\text { (mean change) }\end{array}$ & $\mathbf{0 . 1 *}$ & 0.20 & 0.16 & 0.13 & 0.04 & 0.11 & 0.05 & 0.15 \\
\hline $\begin{array}{l}\text { Control (mean } \\
\text { change) }\end{array}$ & $\mathbf{0 . 0 4}$ & 0.12 & 0.10 & 0.08 & -0.00 & 0.05 & -0.08 & 0.10 \\
\hline Sample size & 704 & 45 & 28 & 20 & 262 & 110 & 66 & 173 \\
\hline
\end{tabular}

Note: Statistically significant results at the $0.05 *$ level, for one-tailed test.

The change scores for Electoral participation varied between -1.40 and 1.60, while the scores for Issue-based participation ranged between -1.67 and 1.68 .

Source: Authors based on conducted research

This brings us to the first important conclusion: the impact of such a cognitively complex activity as competitive debating must be studied within a time-frame longer than one academic year. Students often report significant changes in their way of thinking and immediate effects on their confidence (Akerman and Neale 2011; Rogers 2002), while their teachers perceive gains in their critical thinking skills (Jerome and Algarra 2006; Williams, McGee and Worth 2001). Some of these changes come about relatively soon after starting debating. However, our research shows that several months simply does not offer enough time for young people fully internalise or experience the attitudinal changes. Therefore, it cannot be expected that a survey research design based on self-reporting will reveal statistically significant differences in the behaviour of respondents over a period of less than a year.

Despite the lack of longitudinal effects, our study reached another important conclusion. Competitive debating can be perceived as an educational activity that is more attractive for youths who already have higher levels of political participation or democratic values, and it helps them retain, and potentially improve, these attitudinal traits.

Even if the longitudinal analysis does not prove the impact of debating on certain expected outcomes, it nevertheless demonstrates that the initial differences between debaters and nondebaters remain stable over time. Our data show that debating is an educational activity that 
is more attractive for youths with already higher levels of political participation or democratic values and helps them retain, and potentially improve, these attitudinal traits. Nevertheless, this analysis illustrates how students who participate in debate activities differ from their nondebating peers in terms of their attitudes and values towards the political domain. With that information, we have an insight into what may attract young people to debating and possibly other political education activities.

\section{Conclusion}

The current research on young people's political participation and democratic attitudes has mostly focused on the situation of youths in Western democracies. This article expands on this research by focusing on the so called "new" democracies. The research was conducted in seven countries - the Czech Republic, Estonia, Latvia, Lithuania, Macedonia, Romania, and Slovakia - as part of a wider project studying the impact of debate programme participation on young people. Instead of assessing the current level of political engagement in all of these countries, we explored one specific means through which the political engagement of youths could be facilitated - competitive debating. We focused on the impact of participation in debate programmes, since their assumed mission is to train politically more active and engaged citizens. Our research methods were based on widely accepted techniques for measuring the level of political engagement and capturing democratic attitudes.

Based on the collected empirical evidence, we can conclude that the overall level of political engagement of young people participating in debate programmes in the "new" democracies is considerably higher compared to their non-debating peers in the control groups. Additionally, the debaters' attitudes are more supportive towards values which are the basis for a properly functioning democracy.

The higher levels of political participation apply to both of its recognised alternatives electoral as well as issue-based. Moreover, our data confirm that the trend spotted in the "old" democracies - that young people lean more towards the issue-based forms of political participation compared to the electoral - is also characteristic for youths in "new" political systems with a shorter democratic tradition.

Moreover, we see the competences of debaters more in accordance with desired citizenship characteristics, because they are more inclined to engage in discussions about political topics and their knowledge about institutions and current political issues is higher. However, in some cases debaters declare a lower ability to formulate an opinion on political issues. We believe the reason for this is that competitive debating forces them to examine a topic (and its pros and cons) from various perspectives and therefore when it comes to taking one clear stance, they are less willing to do so compared to their counterparts who are not taught to consider a topic from various angles.

Lastly, the attitudes of debaters are much more supportive of democratic values and the democratic attributes of political systems. This leads us to conclude that they are better able to appreciate the advantages of democratic political systems. The empirical evidence is inconclusive, however, when it comes to debaters' acceptance of various societal groups. Debaters are not always more tolerant of groups that might be stigmatised 
or negatively perceived, and this poses a challenge for the future development of debate programmes in the selected countries.

These differences were observed during both of the testing rounds we conducted, although with only limited statistically significant improvement during the relatively short time period of several months. Therefore, one important methodological conclusion is that for such complex, cognitive activity research, one cannot expect a significant impact within such a short time span. Future research on the impact of debate should extend the period of time between the pre-test and post-test measurement considerably to allow for better exploration of the attitudinal changes brought about by participating in debate activities. In spite of these limitations, we can safely conclude that debating attracts youth who are inclined to be more politically engaged and it could provide them with important skills for their future democratic participation.

\section{Appendix}

Table A1: Variables operationalization

\begin{tabular}{|c|c|c|}
\hline Variables & Measurement & Items included in the survey \\
\hline \multicolumn{3}{|c|}{ I. Political competencies } \\
\hline $\begin{array}{l}\text { Interest in political } \\
\text { issues }\end{array}$ & $\begin{array}{l}\text { Index variable } \\
\text { (4 items) }\end{array}$ & $\begin{array}{l}\text { 1. Interest in politics } \\
\text { 2. Discussing political matters with family } \\
\text { 3. Discussing political matters with friends } \\
\text { 4. Following politics in the news }\end{array}$ \\
\hline Political knowledge & $\begin{array}{l}3 \text { True or False } \\
\text { country specific } \\
\text { questions }\end{array}$ & $\begin{array}{l}\text { Although the questions used were adapted to account for } \\
\text { differences in the political system in each country, they included } \\
\text { aspects such as the name of the prime minister, the number } \\
\text { of MPs etc. The responses were coded as true (1) or false (0), } \\
\text { with the total score ranging from } 0 \text { to } 3 \text {. }\end{array}$ \\
\hline $\begin{array}{l}\text { Understanding } \\
\text { and expressing } \\
\text { political opinions }\end{array}$ & $\begin{array}{l}2 \text { individual } \\
\text { items }\end{array}$ & $\begin{array}{l}\text { 1. How often do you think politics is so complicated that you } \\
\text { cannot really understand what is going on? } \\
\text { 2. How difficult or easy do you find it to formulate an opinion } \\
\text { on political issues? }\end{array}$ \\
\hline \multicolumn{3}{|l|}{ II. Democratic values } \\
\hline $\begin{array}{l}\text { Support for } \\
\text { democracy }\end{array}$ & $\begin{array}{l}\text { Index variable } \\
\text { (7 items) }\end{array}$ & $\begin{array}{l}\text { Support for: } \\
\text { 1. Having a strong leader who does not have to bother with } \\
\text { parliament and elections } \\
\text { 2. Having the army rule the country } \\
\text { 3. Having a democratic political system } \\
\text { 4. Democracy may have problems but it's better than any other } \\
\text { form of government } \\
\text { 5. In democracy, the economic system runs badly } \\
\text { 6. Democracies are indecisive and have too much squabbling } \\
\text { 7. Democracies aren't good at maintaining order }\end{array}$ \\
\hline Tolerance & $\begin{array}{l}\text { Index variable } \\
\text { (15 items*) }\end{array}$ & $\begin{array}{l}\text { Accepting people from various groups as neighbours: People } \\
\text { with a criminal record, People of a different race, Left wing } \\
\text { extremists, Heavy drinkers, Right wing extremists, People with } \\
\text { large families, Emotionally unstable people, Muslims, Immigrants / } \\
\text { foreign workers, People who have AIDS, Drug addicts, } \\
\text { Homosexuals, Jews, Gypsies, Christians }\end{array}$ \\
\hline
\end{tabular}


Anne Valkering, Miroslav Nemčok, George Matu, Peter Spáč: It's More than Just Debating...

\begin{tabular}{|c|c|c|}
\hline Variables & Measurement & Items included in the survey \\
\hline \multicolumn{3}{|l|}{ III. Political Participation } \\
\hline Electoral participation & $\begin{array}{l}\text { Factor scores } \\
\text { (5 items) }\end{array}$ & $\begin{array}{l}\text { Have done, might do, would never do the following: } \\
\text { 1. Become a member of a political organization (political party, } \\
\text { Greenpeace) } \\
\text { 2. Vote when I am of age } \\
\text { 3. Find information about political parties before voting } \\
\text { 4. Help a candidate during the elections } \\
\text { 5. Become a candidate for an election }\end{array}$ \\
\hline $\begin{array}{l}\text { Issue-based } \\
\text { participation }\end{array}$ & $\begin{array}{l}\text { Factor scores } \\
\text { (6 items) }\end{array}$ & $\begin{array}{l}\text { 1. Discuss social and political issues (for example from the news) } \\
\text { on the internet) } \\
\text { 2. Wear a t-shirt or a sticker to convey my opinion } \\
\text { 3. Sign a petition } \\
\text { 4. Stop buying products for political reasons (environment, child } \\
\text { labour) } \\
\text { 5. Gather signatures for a petition } \\
\text { 6. Participate in a lawful protest or demonstration }\end{array}$ \\
\hline
\end{tabular}

* The only exceptions were Lithuania and Romania, where 14 and 13 items were used, respectively, due to low consistency of the scale for some of the items.

Source: Authors

\section{References}

AKERMAN, Rodie and Ian NEALE. 2011. Debating the Evidence: An International Review of Current Situation and Perceptions. Reading: The English-Speaking Union.

ALLEN, Mike, Sandra BERKOWITZ, Steve HUNT and Allan LOUDEN. 1999. "A Meta-analysis of the Impact of Forensics and Communication Education on Critical Thinking." Communication Education 48(1): 18-30.

AMNÅ, Erik and Joakim EKMAN. 2014. "Standby Citizens: Diverse Faces of Political Passivity." European Political Science Review 6(02): 261-281.

BARTANEN, Kristine M. 1998. "The Place of the Forensics Program in the Liberal Arts College of the Twenty-First Century: An Essay in Honor of Larry E. Norton”. Forensic 84(1): 1-15.

BEER, Wolfgang, Will CREMER and Peter MASSING. 1999. Handbuch Politische Erwachsenenbildung. Schwalbach: Wochenschau-Verlag.

BELLON, Joe. 2000. “A Research-Based Justification for Debate across the Curriculum.” Argumentation and Advocacy 36(3): 161-175.

BENNETT, W. Lance and Alexandra SEGERBERG. 2012. "The Logic of Connective Action: Digital Media and the Personalization of Contentious Politics." Information Communication and Society 15(5): 739-768.

BENNETT, W. Lance and Alexandra SEGERBERG. 2013. The Logic of Connective Action: Digital Media and the Personalization of Contentious Politics. Cambridge: Cambridge University Press.

BERGH, Johannes. 2013. "Does Voting Rights Affect the Political Maturity of 16- and 17-Year-Olds? Findings from the 2011 Norwegian Voting-Age Trial." Electoral Studies 32(1): 90-100.

BINNEMA, Harmen, Maud ADRIAANSEN and Dieter VERHUE. 2007. Jonge Burgers En Democratie Kennis, Houding En Vaardigheden. Amsterdam: Veldkamp.

BRAND, Jeffrey. 2000. "Advancing the Discipline: The Role of Forensics in the Communication Field." Forensic 86(1): 1-14.

BURDEWICK, Ingrid. 2003. Jugend - Politik - Anerkennung: Eine Qualitative Empirische Studie Zur Politischen Partizipation 11- Bis 18-Jähriger. Opladen: Leske und Budrich. 
CHAN, Tak Wing and Matthew CLAYTON. 2006. "Should the Voting Age Be Lowered to Sixteen? Normative and Empirical Considerations." Political Studies 54(3): 533-558.

COLBERT, Kent R. 1987. "The Effects of CEDA and NDT Debate Training on Critical Thinking Ability." Argumentation and Advocacy 23(4): 194-201.

CRONIN, Michael. 1990. "Debating to Learn across the Curriculum: Implementation and Assessment." Paper presented at the Southern States Communication Association Convention, Birmingham, Alabama.

DERRYBERRY, Bob R. 1997. "Forensics as a Cooperative Agent: Building a Tradition within an Academic Community." Paper presented at the 83rd Annual Meeting of the National Communication Association in Chicago, Illinois.

ENNIS, Robert H. 1987. "A Taxonomy of Critical Thinking Dispositions and Abilities.” Pp. 9-26 in Teaching Thinking Skills: Theory and Practice, edited by Joan B. BARON and Robert J. STERNBERG. New York: W.H. Freeman/Times Books/ Henry Holt \& Co.

EUROPEAN COMMISSION. 2007. Young Europeans: Survey among Young People Aged between 15-30 in the European Union. Eurobarometer \#202. Analytical Report. The Gallup Organization.

FIELD, Andy P. 2009. Discovering Statistics Using SPSS: (And Sex, Drugs and Rock " $n$ ” Roll). 3rd ed. Los Angeles: SAGE.

GOMEZ, Brad T. and J. Matthew WILSON. 2001. "Political Sophistication and Economic Voting in the American Electorate: A Theory of Heterogeneous Attribution." American Journal of Political Science 45(4): 899-914.

GOODWIN, Jean. 2003. "Students' Perspectives on Debate Exercises in Content Area Classes." Communication Education 52(2): 157-163.

GREEN, Charles S. and Hadley G. KLUG. 1990. "Teaching Critical Thinking and Writing through Debates: An Experimental Evaluation.” Teaching Sociology 18(4): 462-471.

HOOGHE, Marc, Ellen QUINTELIER, Cecil MEEUSEN, Soetkin VERHAEGEN, Joris BOONEN and Aurélie SMETS. 2013. Parent-Child Socialization Study (PCSS) 2012-2013. Technical Report. Leuven: Centre for Citizenship and Democracy.

JEROME, Lee and Bhavini ALGARRA. 2006. English-Speaking Union London Debate Challenge 2005-06. Final Evaluation Report. Cambridge and Chelmsford: Anglia Ruskin University.

KENNEDY, Ruth R. 2009. "The Power of In-Class Debates." Active Learning in Higher Education 10(3): 225-236.

KIRLIN, Mary. 2002. “Civic Skill Building: The Missing Component in Service Programs?” PS: Political Science and Politics 35(3): 571-575.

KITSCHELT, Herbert, Zdenka MANSFELDOVÁ, Radoslaw MARKOWSKI and Gábor TÓKA. 1999. Post-Communist Party Systems: Competition, Representation, and Inter-Party Cooperation. Cambridge: Cambridge University Press.

KLINGEMANN, Hans-Dieter and Dieter FUCHS, eds. 1998. Citizens and the State. Oxford: Oxford University Press.

LIN, Alex. 2015. "Citizenship Education in American Schools and Its Role in Developing Civic Engagement: A Review of the Research.” Educational Review 67(1): 35-63.

MASSING, Peter. 2002. Jugend Und Politik: Jugenddebatten, Jugendforschung, Jugendpolitik. Schwalbach: Wochenschau-Verlag.

McALLISTER, Ian. 1998. "Civic Education and Political Knowledge in Australia." Australian Journal of Political Science 33(1): 7-23.

McFARLAND, Daniel A. and Reuben J. THOMAS. 2006. "Bowling Young: How Youth Voluntary Associations Influence Adult Political Participation." American Sociological Review 71(3): 401-425. 
McFARLAND, Daniel and Carlos E. STARMANNS. 2009. "Inside Student Government: The Variable Quality of High School Student Councils.” Teachers College Record 111(1): 27-54.

MIRAZCHIYSKI, Plamen, Daniel H. CARO and Andrés SANDOVAL-HERNÁNDEZ. 2014. "Youth Future Civic Participation in Europe: Differences between the East and the Rest." Social Indicators Research 115(3): 1031-1055.

NORRIS, Pippa. 2002. Democratic Phoenix: Reinventing Political Activism. New York: Cambridge University Press.

NORRIS, Pippa. 2003. Young People and Political Activism: From the Politics of Loyalties to the Politics of Choice? Report for the Council of Europe Symposium "Young people and democratic institutions: from disillusionment to participation" in Strasbourg.

NUGENT, Richard. 2006. "Civic, Social and Political Education: Active Learning, Participation and Engagement?" Irish Educational Studies 25(2): 207-229.

OWEN, Diana, Rebecca CHALIF and Suzanne SOULE. 2011. Civic Education and Knowledge of Government and Politics. Paper presented at the American Political Science Association Annual Meeting in Palm Desert, California.

PETTIGREW, Thomas F. and R. W. MEERTENS. 1995. "Subtle and Blatant Prejudice in Western Europe.” European Journal of Social Psychology 25(1): 57-75.

QUINTELIER, Ellen. 2007. "Differences in Political Participation between Young and Old People." Contemporary Politics 13(2): 165-180.

REICHERT, Frank and Murray PRINT. 2017. "Civic Participation of High School Students: The Effect of Civic Learning in School.” Educational Review 70(3): 318-341.

RHOMBERG, Markus. 2009. Politische Kommunikation. Paderborn: Wilhelm Fink Verlag.

ROGERS, Jack E. 2002. "Longitudinal Outcome Assessment for Forensics: Does Participating in Intercollegiate, Competitive Forensics Contribute to Measurable Differences in Positive Student Outcomes?" Contemporary Argumentation \& Debate 23(1).

SANDERS, Judith A., Richard L. WISEMAN and Robert H. GASS. 1994. "Does Teaching Argumentation Facilitate Critical Thinking?” Communication Reports 7(1): 27-35.

SLOAM, James. 2016. "Diversity and Voice: The Political Participation of Young People in the European Union.” The British Journal of Politics and International Relations 18(3): 521-537.

STADELMANN-STEFFEN, Isabelle and Linda SULZER. 2017. "Just Another Brick in the Wall? The Relationship between Classroom-Based Political Education and the Political Interest of Young Adults in Switzerland." Journal of Youth Studies 21(4): 552-575.

TORNEY-PURTA, Judith V. 2009. "International Psychological Research That Matters for Policy and Practice." American Psychologist 64(8): 825-837.

WILLIAMS, David E., Brian R. McGEE and David S. WORTH. 2001. "University Student Perceptions of the Efficacy of Debate Participation: An Empirical Investigation." Argumentation and Advocacy 37(4): 198-209.

YOLDAŞ, Özlem Becerik. 2015. "Civic Education and Learning Democracy: Their Importance for Political Participation of Young People.” Procedia - Social and Behavioral Sciences 174(286): 544-549.

YOUNISS, James, Jeffrey A. McLELLAN and Miranda YATES. 1997. "What We Know About Engendering Civic Identity.” American Behavioral Scientist 40(5): 620-631. 